\title{
BERAT DAN PANJANG BAYI SERTA NILAI Z SKOR BAYI DENGAN ASI PREDOMINAN DAN PARSIAL BERDASARKAN STANDAR WHO 2005 DAN NCHSIWHO
}

(Analisis data sekunder Penelitian Kohor Prospektif : Pengaruh Pemberian MP-ASI Dini terhadap Gangguan Pertumbuhan Bayi dengan Berat Lahir Normal sampai Umur 4 bulan)

\author{
Anies Irawati ${ }^{1}$; Endang L. Achadi ${ }^{2}$ dan Abas B Jahari ${ }^{1}$ \\ Puslitbang Gizi dan Makanan, Badan Litbangkes, Dep.Kes RI \\ ${ }^{2}$ Fakultas Kesehatan Masyarakat - Universitas Indonesia
}

\begin{abstract}
New WHO standard introduce to implemented in every country including Indonesia. The population of children to develop new standard comes from good economic status and low mobility. Three quarters infant were exclusive/predominantly breastfed for at least four month. In Indonesia, predominantly and partially breastfed most practiced than exclusive breastfeeding. To compare the growth of infants according to WHO new standard and NCHS reference. Methods: Analyzed using secondary data of cohort prospective research of "the influence early supplementation infant feeding to first four month infant growth". Developing curve of infant weight and length attainment for predominant and partially breastfed; also developing curve Z score (weight for age, weight for length and length for age) for predominant and partially breastfed. Both curves development are using new WHO standard and NCHS reference. During the first four month, the weight and length deviation of infant with predominantly and partially breastfed using new who standard larger than NCHS, and infant with predominantly breastfed better than partially breastfed. The $Z$ score curve for weight for age, length for age and weight for age simultaneously as a pattern of new WHO standard, but since birth until 4 month age the number of $Z$ score for those indicators lower than WHO new standard. New WHO standard anthropometry more representative to infant growth than NCHS reference.
\end{abstract}

Keywords: Predominant breastfed infants, partially breastfed infants, growth curve, New WHO standard, NCHS reference

\section{PENDAHULUAN}

$\mathrm{P}$ ada tahun 2006 standar antropometri baru yang disebut 'standar antropometri WHO 2005' mulai diperkenalkan. Standar WHO ini menggunakan populasi anak balita dari enam negara termasuk Asia, yaitu Brazil, Ghana, India, Norway, Oman dan USA. Populasi anak balita yang dilibatkan untuk mengembangkan WHO growth standard 2005 ini tinggal di keluarga dengan keadaan sosial ekonomi yang favourable untuk tumbuh dan mobilitas rendah. Seperempat bayi mendapat ASI eksklusif/ASI predominan sedikitnya selama 4 bulan.
Kriteria inklusi sampel anak balita WHO growth standard 2005 adalah tidak tinggal di lingkungan yang memungkinkan terjadinya gangguan pertumbuhan, ibu bersedia mengikuti MGRS (Multicenter Growth Reference Study), ibu bersedia mematuhi pemberian makan pada balita sesuai rekomendasi MGRS (ASI eksklusif atau ASI predominan sedikitnya selama 4 bulan, memperkenalkan MP-ASI ketika bayi berumur 6 bulan, dan melanjutkan memberikan ASI sampai sedikitnya bayi berumur 12 bulan), ibu tidak merokok sebelum dan sesudah melahirkan, kelahiran tunggal dan cukup bulan serta tidak sakit (WHO, 2006). Pengukuran terhadap berat 
badan dan panjang badan pada bayi sampai usia 59 bulan dilakukan setiap bulan. Dengan populasi yang lebih bervariasi, dengan kriteria inklusi tersebut diatas serta frekuensi pengukuran yang lebih sering, maka dapat diharapkan bahwa Standar antropometri WHO 2005 akan lebih merepresentasikan pola pertumbuhan yang optimal untuk semua ras.

Standar antropometri yang baik dapat digunakan untuk berbagai tujuan, termasuk mengukur dan memonitor prevalensi malnutrisi dan pola pertumbuhan bayi dan anak-anak, serta untuk membandingkan pola pertumbuhan bayi dan anak-anak berdasarkan berbagai faktor, antara lain praktek pemberian ASI, yang saat ini menjadi perhatian karena rendahnya prevalensi pemberian ASI eksklusif. Misalnya beberapa penelitian longitudinal membuktikan bahwa hanya kurang dari $5 \%$ bayi di Indonesia yang mendapatkan ASI eksklusiflpredominan (Irawati, 2004; Utomo,1996; Kusharisupeni, 1999; Kusin dan Kardjati, 1994). Untuk itu perlu dikaji apakah pertumbuhan bayi yang mendapatkan ASI eksklusif predominan untuk waktu yg dianjurkan akan mempengaruhi pertumbuhan bayi tersebut.

Paper ini menguraikan hasil kajian pencapaian berat dan panjang bayi serta nilai Z skor bayi yang mendapat ASI predominan dan ASI parsial dengan menggunakan standar antropometri WHO 2005. Analisis pada paper ini menggunakan data sekunder penelitian tentang pengaruh pemberian makanan pendamping ASI dini terhadap gangguan pertumbuhan bayi lahir normal sampai umur 4 bulan.

\section{METODE}

\section{Pengumpulan data penelitian}

Data yang digunakan berasal dari penelitian kohor prospektif pada sebanyak 234 pasang ibu dan bayi yang dipantau sejak bayi lahir sampai berumur 4 bulan, yang dilakukan di Kecamatan Sukaraja, Kabupaten Bogor. Penelitian dilakukan selama 21 bulan (Maret 2002 sampai dengan November 2003). Kriteria Inklusi sampel adalah bayi lahir cukup bulan, bayi lahir normal (tidak cacat), berat bayi lahir normal, bayi lahir tunggal, sampai umur 4 bulan bayi masih mendapat ASI dan ibu tidak menderita sakit menahun.

Data yang dikumpulkan dan diperlukan untuk analisis paper ini adalah umur bayi, berat dan panjang bayi sejak lahir sampai umur 4 bulan. Pada saat penelitian ini dilakukan, Departemen Kesehatan menetapkan pemberian ASI eksklusif sedikitnya selama 4 bulan, dan pada bulan April 2004 melalui SK Menkes No. 450IMenkesISKIIVI2004 tentang pemberian Air Susu Ibu (ASI) secara eksklusif pada bayi di Indonesia sedikitnya selama 6 bulan. Data berat dan panjang bayi lahir dikumpulkan dalam 24 jam setelah bayi dilahirkan. Berat bayi ditimbang dengan timbangan digital merk Hitachi dengan ketelitian 10 gram dan panjang bayi diukur dengan papan pengukur panjang bayi dilengkapi pita microtoise dengan ketelitian 0,1 cm. Pengukuran konsumsi ASI, dibedakan antara predominan dan parsial. Mengacu pada kriteria breastfeeding $\mathrm{WHO}$ bayi dengan ASI predominan didefinisikan sebagai bayi yg mendapat ASI dan cairan (madu, air putih, air teh) tetapi tidak mendapat makanan padatlsemi padat. Sedangkan bayi ASI parsial didefinisikan sebagai bayi yg mendapat ASI dan cairan juga makanan padatlsemi padat (WHO 2002, WHO 2006).

\section{Analisis data}

Analisis data untuk paper ini dilakukan dengan membuat kurva panjang badan dan berat badan bayi penelitian yang kemudian dibandingkan dengan standar WHO 2005 dan standar NCHS. Selanjutnya data panjang badan, berat badan dan umur dianalisis menurut nilai z-skor dengan menggunakan standar $\mathrm{WHO}$ dan NCHS. Nilai rata-rata z-core berdasarkan kedua standar tersebut kemudian dibuat kurva. Analisis dilakukan dengan membedakan jenis kelamin dan pola pemberian ASI (predominan dan parsial) 


\section{DASAR PEMIKIRAN}

Dalam rangka membandingkan posisi status gizi bayi Indonesia dengan standar WHO, maka perlu dilakukan analisis terhadap situasi status gizi bayi di Indonesia, sebagai pertimbangan dalam melakukan interpretasi.

Gambar 1 berikut menunjukkan pola pertumbuhan anak balita di Indonesia sejak tahun 1989 sampai dengan tahun 2005 yang bersumber dari data SUSENAS. Walaupun membaik dibandingkan tahun-tahun sebelumnya, gambar diatas menunjukkan bahwa bayi pada waktu lahir berada pada kisaran z-skor $0.5-0.0$, artinya berada pada batasan marginal bila dibandingkan dengan standar WHO. Telah diketahui bahwa bayi yang lahir dengan berat badan kurang optimal menunjukkan bahwa telah terjadi hambatan pada pertumbuhan semasa janin.
Selanjutnya gambar 1 menunjukkan bahwa telah terjadi growth faltering secara tajam sejak usia sangat dini, dan menetap jauh dibawah standar WHO walaupun masih berada pada batasan >-2SD. Apakah hal ini terkait dengan praktek pemberian ASI eksklusif, perlu dikaji lebih jauh. Namun, memang terdapat kecenderungan penurunan pemberian ASI eksklusif sejak dekade terakhir, dan data SDKI 200212003 menunjukkan bahwa hanya $13.9 \%$ bayi usia 4-5 bulan yang masih mendapatkan ASI eksklusif. Berbagai penelitian menunjukkan bahwa gangguan pertumbuhan janin akan menyisakan efek (retained effect) terhadap pertumbuhan selanjutnya. Berlanjutnya masalah pertumbuhan yang ditunjukkan dengan terjadinya growth faltering pada usia dini mengindikasikan bahwa hambatan pertumbuhan pada masa janin berlanjut ke masa pasca-salin.

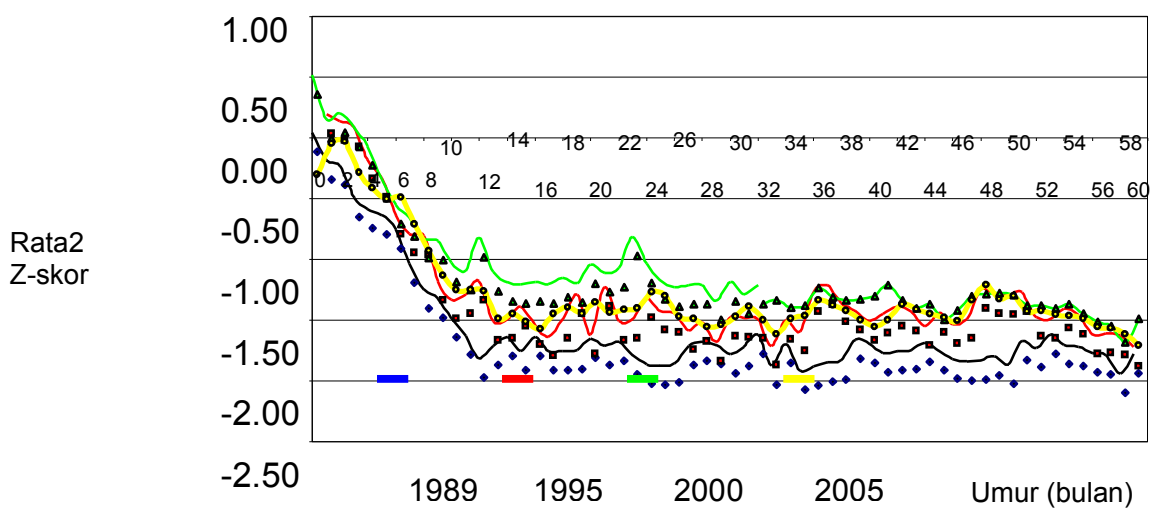

Gambar 1. Kejadian Growth faltering antara usia 0-4 bulan, 1989-2005

(Sumber: Atmarita, Jogya, Juli 2006)

Selanjutnya, penelitian di Bogor (Iman dkk, 2005) menunjukkan prevalensi kurang Gizi pada bayi 0-5 bulan. Analisis data penelitian ini dilakukan dengan menggunakan standar WHO 2005 dan rujukan NCHS. 


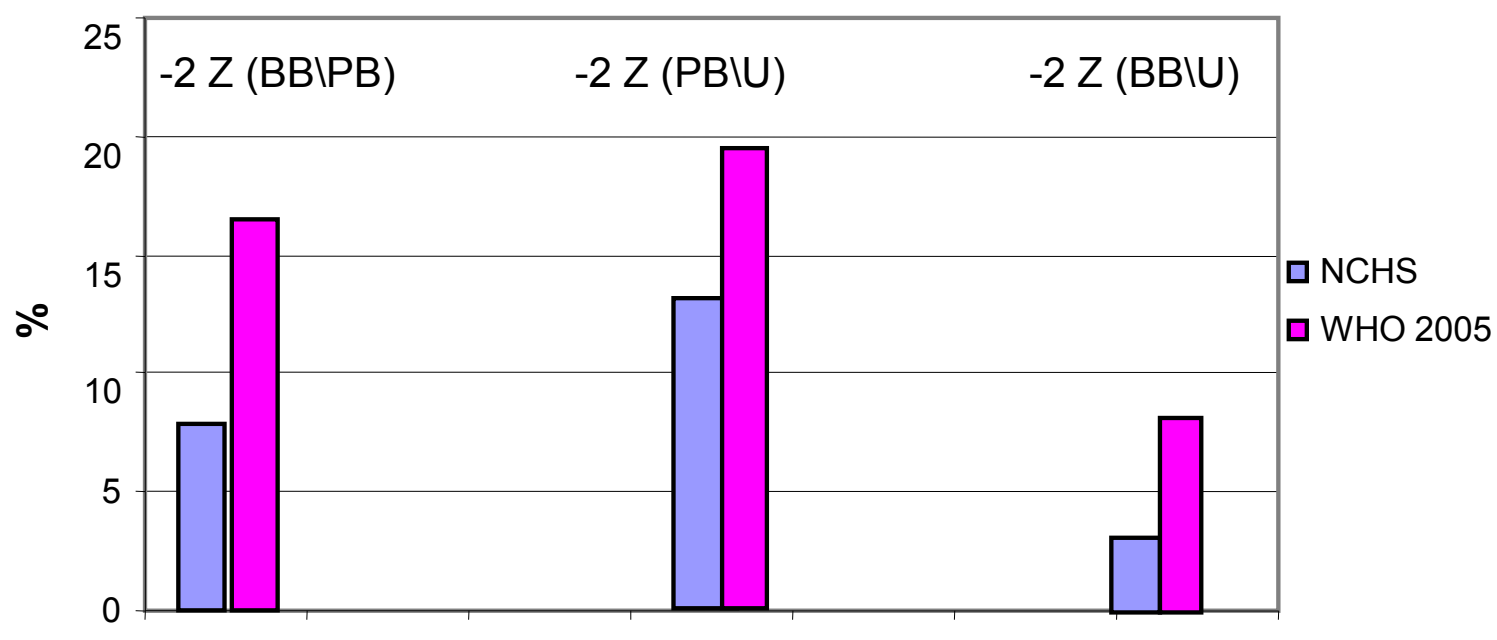

Gambar 2. Prevalensi Gizi Kurang pada Bayi 0-5 bulan

(Sumber: Iman, Jogya, Juli 2006)

Secara umum seperti telah diperkirakan, prevalensi kurang gizi berdasarkan BB/U, BB/PB dan PB/U lebih tinggi bila menggunakan standar $\mathrm{WHO}$ dibandingkan dengan rujukan NCHS, namun demikian kecenderungan prevalensi kurang gizi antara standar WHO dan NCHS sama, yaitu prevalensi kurang gizi berdasarkan $\mathrm{PB} /$ $U$ lebih tinggi dibandingkan dengan berdasarkan BB/PB, dan dibandingkan dengan berdasarkan BB/U. Tampaknya kurang gizi kronis (berdasarkan PB/U) lebih merupakan masalah dibandingkan dengan kurang gizi akut (BB/TB), walaupun masalah gizi akut juga cukup tinggi. Dengan demikian data ini juga menunjang ulasan di atas bahwa bayi mengalami kekurangan gizi sejak janin yang berlanjut pada masa bayi, sehingga deviasi status gizi semakin melebar dengan bertambahnya usia.

Berdasarkan ke dua data di atas, dalam melakukan analisis data penelitian ini terhadap standar WHO 2005 dan WHO/NCHS digunakan asumsi sebagai berikut:

1. Pada usia nol bulan, diperkirakan status gizi sudah berada di bawah WHO, sehingga diperkirakan pola pertumbuhan pasca lahir kurang optimal (tidak mengikuti pola yang seharusnya). Artinya kurva pertumbuhan bayi pada penelitian ini seharusnya paralel di bawah kurva WHO 2005, kecuali kalau terjadi hambatan pertumbuhan pasca salin.

2. Terjadi deviasi antara data penelitian dengan standar WHO, dan diperkirakan semakin melebar apabila status gizi sub-optimal tersebut berlanjut sampai pada masa pasca-lahir yang disebabkan oleh faktor-faktor pengaruh, a.I. pola pemberian makanan/ASI

3. Khusus untuk data penelitian ini, deviasi terhadap normal diharapkan tidak terlalu besar karena karakteristik sampel. Pada penelitian ini dipilih sampel yang tidak mengalami lahir dengan berat badan rendah (BBLR) dan sehat, namun berasal dari keluarga dengan keadaan sosial-ekonomi yang rendah.

Selain itu, standar WHO 2005 dan WHO-NCHS memang berbeda terutama pada usia 6 bulan pertama. Panjang badan bayi/anak dengan standar WHO 2005 lebih tinggi dibandingkan dengan WHO-NCHS, sementara BB/U hanya pada usia 6 bulan pertama lebih tinggi, selanjutnya lebih 
rendah. Dengan demikian dapat diharapkan bahwa prevalensi kurang gizi lebih besar pada usia 6 bulan pertama bila menggunakan standar WHO 2005 dibandingkan menggunakan WHO-NCHS, pada umur yang selanjutnya prevalensinya lebih kecil. Sedangkan prevalensi bayi pendek lebih besar untuk usia 6 bulan pertama dan umur selanjutnya.

\section{HASIL ANALISIS}

Kajian analisis disajikan dalam empat bagian yaitu pencapaian panjang bayi, pencapaian berat bayi, serta perbandingan nilai Z skor bayi laki-laki dan nilai Z skor bayi perempuan dengan standar WHO.

\section{Pencapaian panjang bayi (laki - laki dan perempuan)}

Gambar 3 menunjukkan bahwa pada usia 0 bulan, berat badan bayi laki-laki dan perempuan, baik pada bayi predominan maupun parsial ASI, lebih pendek dibandingkan dengan WHO 2005 dan terutama dengan WHO/NCHS. Sampai usia bayi 2 bulan, kurva bayi pada penelitian sejajar dengan stándar WHO 2005. Sementara kurva WHO/NCHS dan WHO 2005 pada usia 1-3 bulan hampir sejajar, tidak demikian dengan bayi penelitian ini, dimana kurva bayi mulai menjauhi kurva WHO pada usia 2 bulan, dan pada usia bayi 4 bulan terdapat deviasi sebesar $2,1 \mathrm{~cm}$ baik terhadap kurva WHO 2005 maupun terhadap WHO/NCHS.

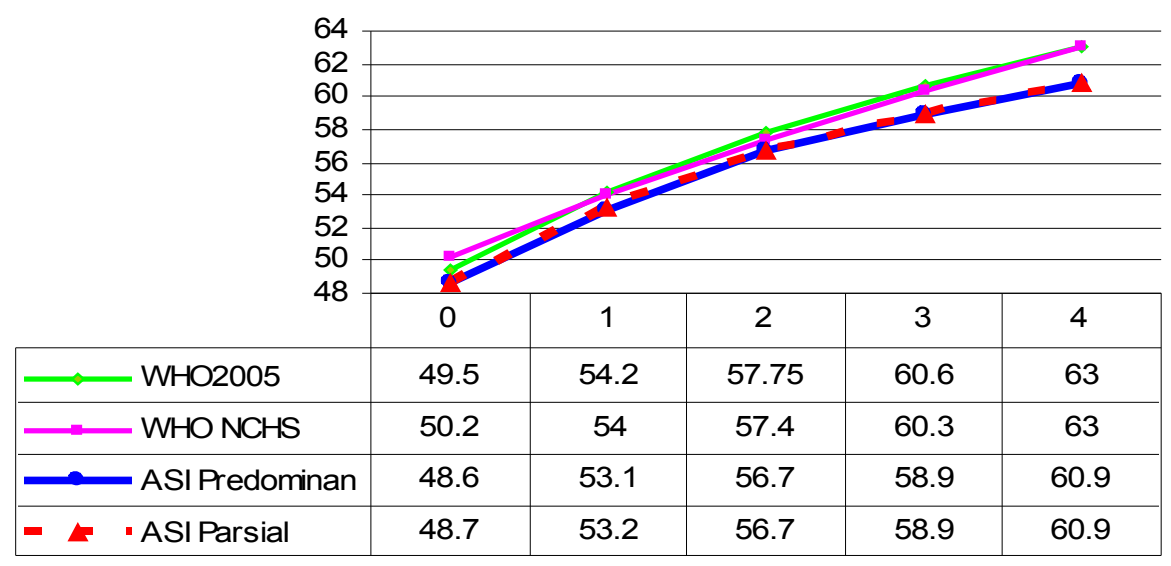

Gambar 3. Pencapaian Panjang Bayi Laki-Laki dan Perempuan Terhadap Standar Antopometri WHO 2005 dan NCHS 1989 (N = 234) 


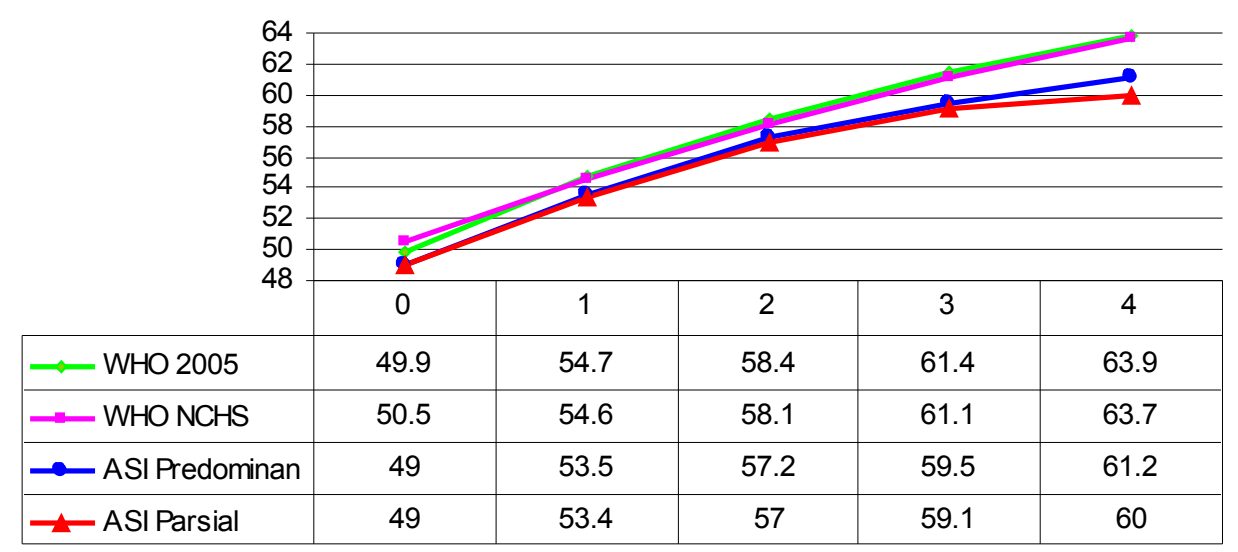

Gambar 4. Pencapaian Panjang Bayi Laki-Laki Terhadap Standar Antopometri WHO 2005 dan NCHS 1989 (N=132)

Pada bayi laki-laki, sejak 0 bulan terdapat defisit panjang badan bila dibandingkan dengan standar WHO maupun NCHS. Kurva bayi penelitian ini sejajar dengan kedua standar sampai usia 2 bulan, terjadi deviasi dengan bertambahnya umur, dan pada usia 4 bulan perbedaan deviasi antara bayi penelitian dengan WHO adalah sebesar $2,7 \mathrm{~cm}$ pada ASI predominan dan $3,9 \mathrm{~cm}$ pada bayi ASI parsial. Deviasi panjang bayi ASI parsial terhadap bayi predominan ASI terjadi mulai sejak usia 1 bulan dan semakin menjauh dengan bertambahnya umur bayi, sehingga pada usia 4 bulan terdapat perbedaan deviasi sebesar $1,2 \mathrm{~cm}$.

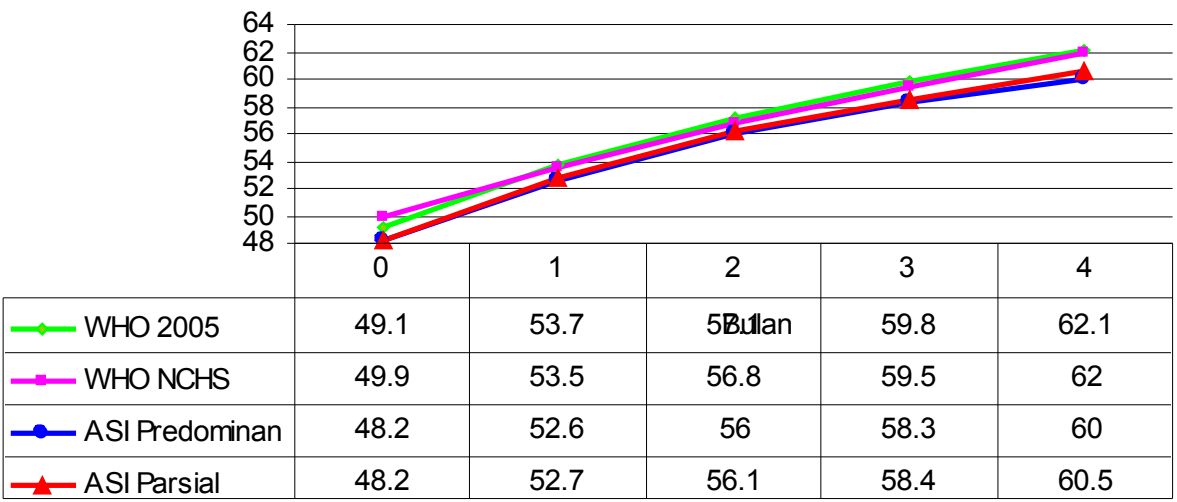

Gambar 5. Pencapaian Panjang Bayi Perempuan Terhadap Standar Antopometri WHO 2005 dan NCHS 1989 (N = 102) 
Sama seperti pada bayi laki-laki, bayi perempuan sejak 0 bulan terdapat defisit panjang badan antara kedua standar. Kurva bayi penelitian ini sejajar dengan standar WHO 2005 sampai 2 bulan, kemudian terjadi deviasi dengan bertambahnya umur, dan pada usia 4 bulan perbedaan deviasi antara bayi penelitian dengan $\mathrm{WHO}$ adalah sebesar 2,1 cm pada ASI predominan dan 1,6 cm pada bayi ASI parsial. Artinya terdapat defisit panjang badan sebesar $3,4 \%$ pada bayi ASI predominan dan $2,6 \%$ pada bayi dengan ASI parsial. Deviasi panjang pada bayi ASI parsial dengan bayi predominan ASI tidak begitu berbeda.

\section{Pencapaian berat bayi (laki - laki dan perempuan)}

Pada Gambar 6, ternyata berat badan rata-rata bayi, baik yang mendapatkan ASI predominan maupun yang mendapatkan ASI parsial, kurang dari 3000 gram, cukup jauh dari standar WHO maupun NCHS. Menarik untuk dikaji bahwa kurva NCHS mengalami deviasi terhadap kurva WHO dengan bertambahnya umur. Pada 2 bulan pertama kehidupannya, kurva berat badan bayi penelitian lebih sejajar dengan kurva WHO dibandingkan kurva NCHS, kemudian terjadi deviasi terutama pada kelompok bayi dg ASI parsial. Pada bayi dengan ASI parsial pada umur 4 bulan, perbedaan berat badan tersebut mencapai $0,9 \mathrm{~kg}$, atau defisit sebesar $13,4 \%$ terhadap standar WHO.

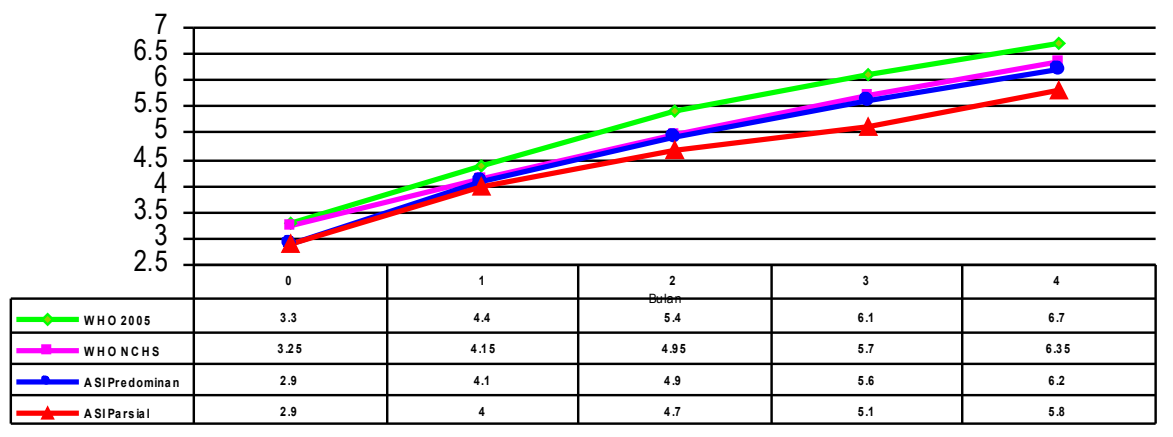

Gambar 6. Pencapaian Berat Bayi Laki-Laki dan Perempuan terhadap Standar Antopometri WHO 2005 dan NCHS 1989 (N = 234)

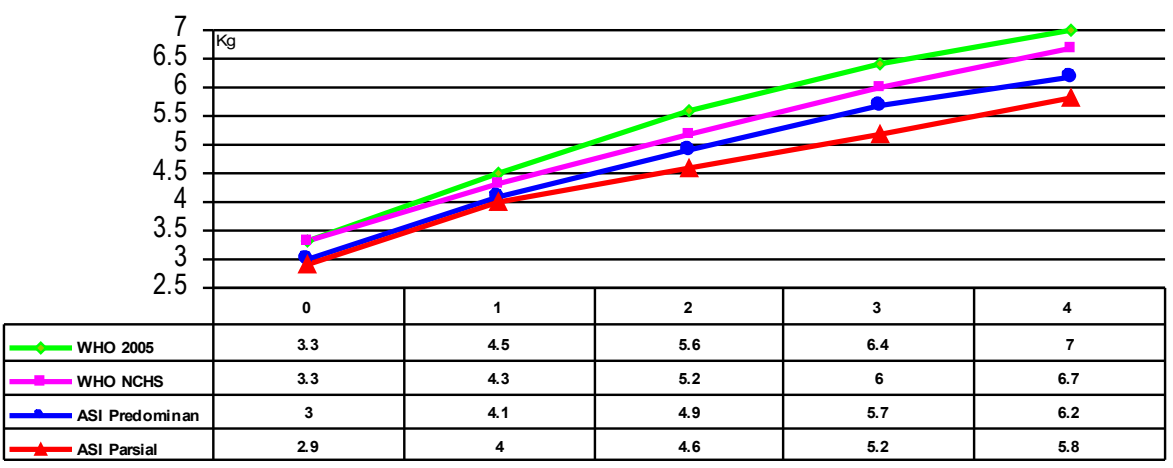

Gambar 7. Pencapaian Berat Bayi Laki-Laki Terhadap Standar Antopometri WHO 2005 dan NCHS 1989 (N = 132) 
Gambar 7 menunjukkan bahwa berat badan rata-rata bayi, baik yang mendapatkan ASI predominant maupun yang mendapatkan ASI parsial berada cukup jauh dari standar WHO maupun NCHS. Deviasi kurva berat badan bayi penelitian telah terjadi sejak bayi berusia 1 bulan, dan semakin besar dengan bertambahnya umur, terutama pada bayi dengan ASI parsial.
Pada umur 4 bulan perbedaan berat badan antara bayi dengan ASI parsial dengan standar WHO adalah 1,2 kg sementara ASI predominan adalah $0,8 \mathrm{~kg}$. Defisit ini cukup besar pada usia yg sangat dini, sebab berarti pada bayi dengan ASI parsial terdapat $17,1 \%$ dan pada ASI predominant terdapat 11,4\% defisit terhadap standar.WHO 2005.

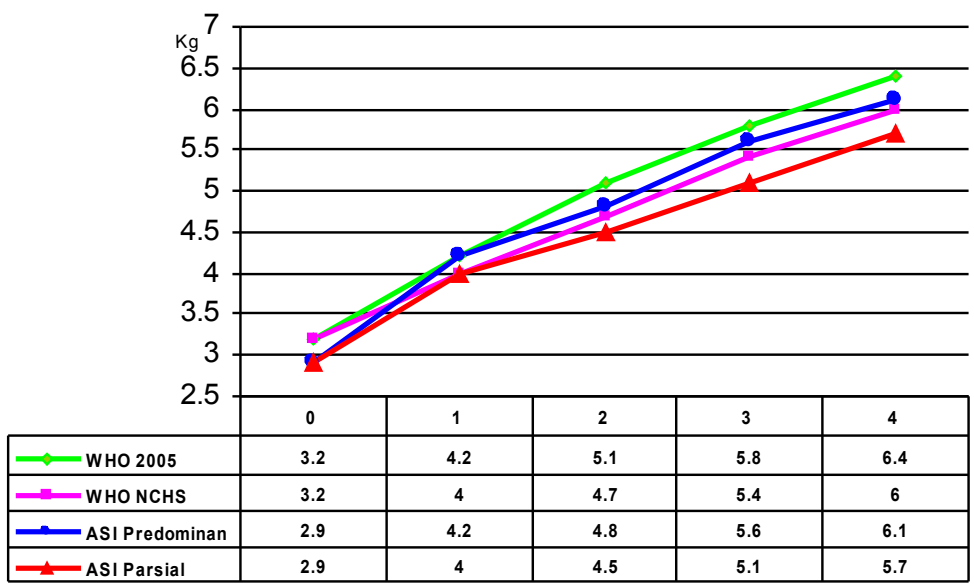

Gambar 8. Pencapaian Berat Bayi Perempuan Terhadap Standar Antopometri WHO 2005 dan NCHS 1989 (N = 102)

Berat bayi pada 0 bulan lebih rendah dibandingkan kedua standar. Selanjutnya kurva berat badan bayi dengan ASI predominan memotong kurva NCHS pada umur 1 bulan dan tetap berada di atas kurva NCHS sampai usia 4 bulan. Sebaliknya pada ASI parsial, deviasi terhadap kedua standar semakin lebar dengan bertambahnya umur. Bila dibandingkan dengan bayi laki-laki, deviasi berat badan pada bayi perempuan kurang nyata dibandingkan dengan pada bayi laki-laki. Perbedaan berat badan antara bayi yang diberi ASI parsial dan predominan adalah sebesar 0,4 kg pada umur bayi 4 bulan.

Dari ulasan temuan diatas, dapat disimpulkan bahwa pola pertumbuhan bayi penelitian lebih sesuai dengan standar WHO 2005 seperti yg diindikasikan oleh sejajarnya kurva pertumpuhan bayi penelitian dengan kurva WHO, paling tidak dalam usia 2 bulan pertama, sementara terhadap kurva NCHS pola pertumbuhan bayi penelitian tidak konsisten.

Sampel standar WHO adalah bayi yang diberi ASI eksklusif. Penelitian ini menunjukkan bahwa keuntungan praktek pemberian ASI predominan terhadap ASI parsial terhadap pertumbuhan bayi ditunjukkan oleh lebih baiknya kurva panjang badan dan berat badan bayi dengan ASI predominan, baik pada bayi laki-laki maupun pada bayi perempuan, dibandingkan dengan bayi dengan ASI parsial.

\section{Nilai z skor pada bayi Laki-Laki}

Secara umum, standar status gizi menurut berat badan dan umur menunjukkan perbedaan antara standar WHO dan NCHS, namun tidak konsisten. Pada usia 6 bulan 
pertama standar NCHS berada dibawah standar WHO, sedangkan pada usia yg lebih tua diatas WHO. Perbedaan antara standar WHO dengan NCHS terlihat jelas pada usia 6 bulan pertama dan diatas 28 bulan. Pada usia 0-6 bulan, kurva NCHS pada z-skor -3 jauh lebih rendah dibandingkan dengan kurva WHO, demikian pula pada usia diatas 28 bulan pada z-skor +3. Artinya, dapat diharapkan bahwa prevalensi bayi 0-6 bulan dengan z-skor $\leq-3$ SD akan lebih besar bila menggunakan standar WHO, dan prevalensi bayi > 28 bulan dengan z-skor > 3 SD akan lebih besar bila menggunakan standar WHO. Sementara itu, bayi dengan nilai z-skor > - 3 SD tidak akan begitu terpengaruh.

Berdasarkan hal tersebut, maka dapat diharapkan bahwa nilai z-skor BB/U bayi pada usia 6 bulan pertama akan jauh lebih rendah bila menggunakan standar WHO dibandingkan dengan bila menggunakan standar NCHS. Artinya, prevalensi kurang gizi jauh lebih tinggi bila menggunakan standar WHO dibandingkan dengan menggunakan standar NCHS. Hal ini terlihat pada Gambar 9.

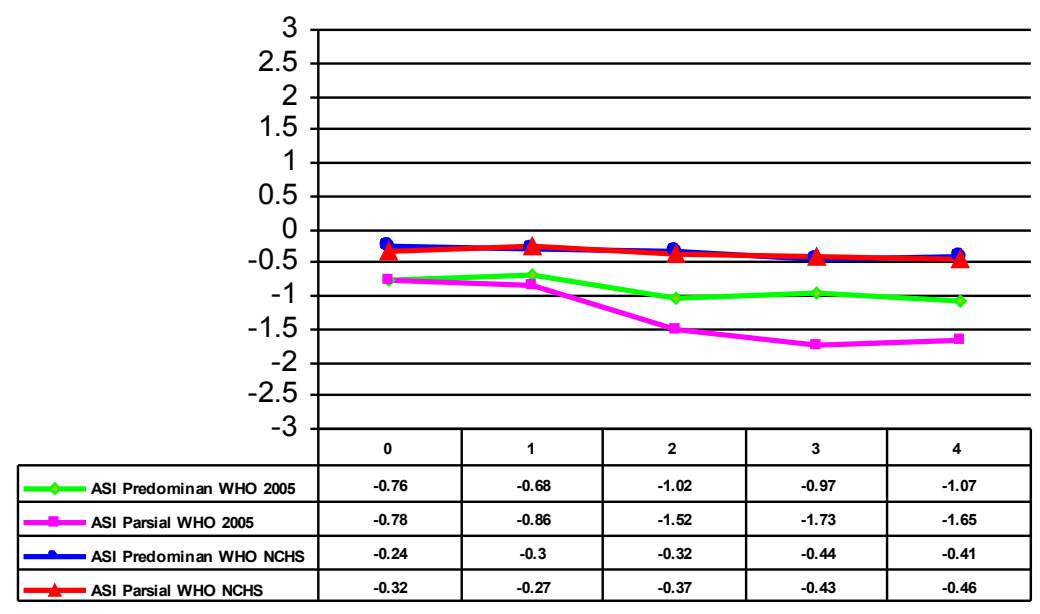

Gambar 9. Nilai Z skor BB/U Bayi Laki-Laki Menggunakan Standar Antopometri WHO 2005 dan WHO NCHS (N = 132)

Nilai z skor berat badan terhadap umur ternyata berada dibawah nilai 0 , walaupun masih berada pada > - 2 SD. Nilai z-skor berdasarkan standar NCHS lebih tinggi dibandingkan dengan WHO. Namun demikian standar NCHS tidak membedakan kurva z-skor antara bayi dg ASI predominant dan ASI parsial. Sedangkan dengan standar WHO, terlihat adanya perbedaan kurva bayi ASI predominan dengan ASI parsial yang semakin nyata dengan bertambahnya umur. Pada usia 4 bulan nilai z skor bayi dengan ASI parsial adalah $-1,65$, sedangkan pada bayi dengan ASI predominan lebih baik, yaitu $-1,07$ (Gambar 9).
Untuk kurva nilai Z-skor PB/U berdasarkan WHO dan NCHS agak berbeda. Secara konsisten pada usia 0-24 bulan, kurva NCHS berada dibawah kurva WHO pada nilai z-skor yg rendah $(<0)$ dan sebaliknya pada nilai Z-skor yang tinggi (> 0). Setelah usia 24 bulan standar NCHS selalu berada dibawah standar WHO. Dengan demikian berarti bahwa bila menggunakan standar WHO maka bayi 0-24 bulan yang mempunyai Z-skor < 0 akan mempunyai Z-skor yg lebih rendah bila dibandingkan dengan menggunakan standar NCHS, dan sebaliknya. Sedangkan pada bayi yang berusia lebih dari 24 bulan, bila menggunakan standar WHO maka nilai Z- 
skor nya akan selalu lebih rendah dibandingkan dengan bila menggunakan NCHS, berapapun nilai z-skornya. Artinya, bila menggunakan standar WHO, maka prevalensi stunted akan lebih besar dibandingkan menggunakan NCHS. Keadaan ini sesuai dengan gambaran pada Gambar 10 di bawah ini.

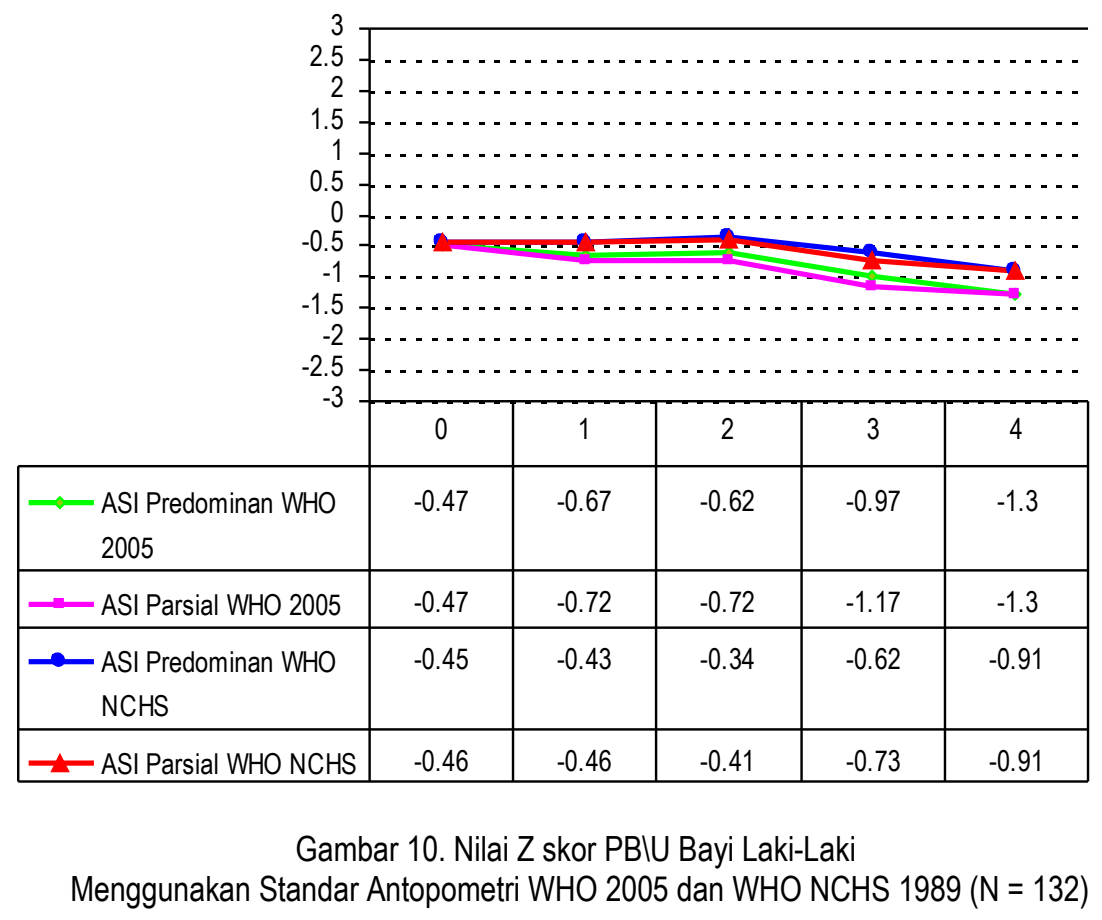

Nilai z skor panjang badan terhadap umur ternyata juga berada dibawah 0 tetapi masih berada pada > -2SD. Nilai z-skor dengan menggunakan standar WHO lebih rendah dibandingkan dengan menggunakan standar NCHS, dan perbedaan tersebut semakin besar dengan bertabahnya umur. Namun baik dengan menggunakan standar WHO maupun NCHS, tidak terlihat adanya perbedaan nilai z-skor antara bayi ASI parsial dengan ASI predominan, artinya perbedaan cara pemberian makanan bayi dalam 6 bulan belum cukup untuk menyebabkan perbedaan terhadap panjang badan.

Pola BB/PB berdasarkan WHO dan NCHS cukup menarik. Nilai z-skor NCHS lebih tinggi pada nilai z-skor yg lebih tinggi (> o SD), dan sebaliknya pada nilai yg lebih rendah. Hal ini tampak pada Gambar 11. Karena nilai z-skor bayi penelitian dibawah 0 , maka dapat diharapkan bahwa bila menggunakan standar WHO maka nilai zskornya akan lebih rendah. 


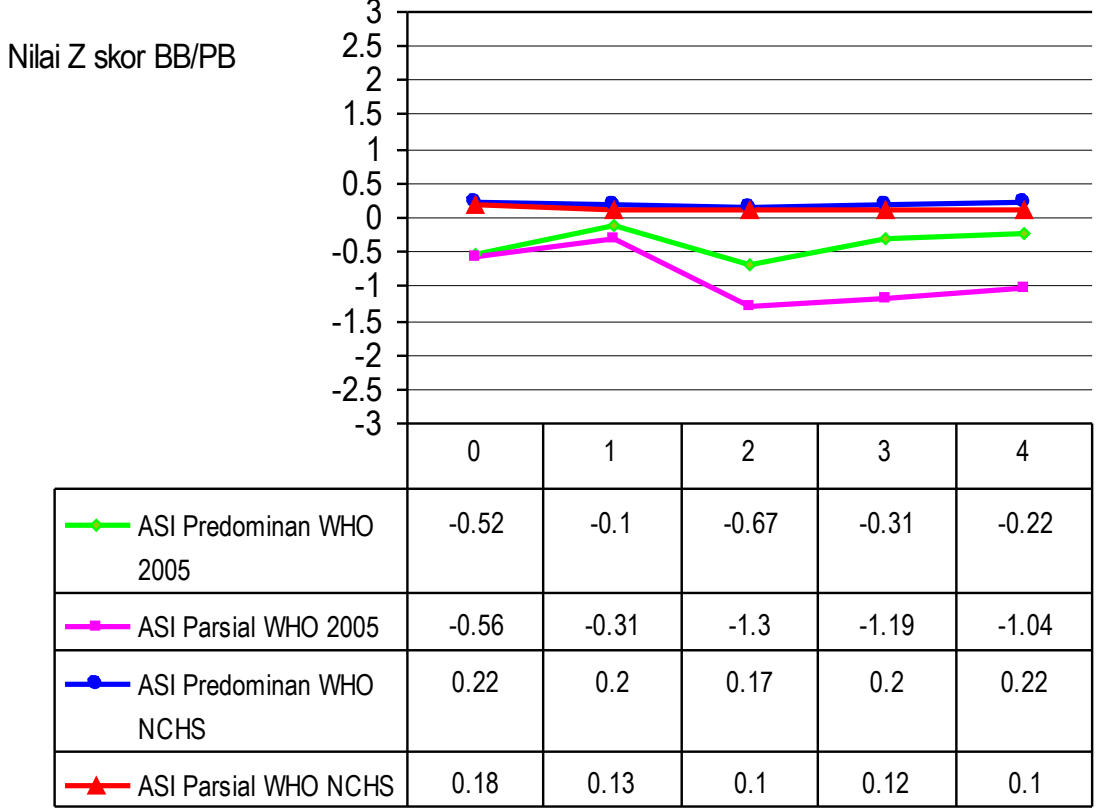

\section{Gambar 11. Nilai Z skor BBIPB Bayi Laki-Laki Menggunakan Standar Antopometri WHO 2005 dan WHO NCHS ( $N=132)$}

Nilai $\mathrm{z}$ skor berat badan terhadap panjang badan dengan menggunakan WHO berada dibawah nilai Z-skor bila menggunakan NCHS. Deviasi nilai Z-skor ASI parsial terhadap ASI predominan tidak berbeda bila menggunakan standar NCHS, sedangkan bila menggunakan standar WHO terlihat jelas, terutama dengan bertambahnya umur. Pada usia 4 bulan nilai z skor bayi dengan ASI parsial berbeda sebesar 0,82 .

\section{Nilai Z skor pada bayi Perempuan}

Kurva nilai z-skor BB/U WHO lebih tinggi dibandingkan kurva NCHS pada usia 0-6 bulan. Dengan demikian bisa diharapkan bahwa penggunaan standar WHO akan memberikan nilai z-skor yang lebih rendah, seperti yang ditunjukkan oleh gambar berikut, selanjutnya prevalensi kurang gizi akan lebih tinggi.

Nilai z-skor dengan menggunakan standar WHO lebih rendah bila dibandingkan dengan menggunakan standar NCHS. Seperti pada bayi laki-laki, nilai Z-skor dengan menggunakan NCHS tidak membedakan nilai Z-skor bayi dengan ASI parsial terhadap bayi dengan ASI predominan. Sebaliknya bila menggunakan standar WHO, perbedaan tersebut jelas. Bayi dengan ASI parsial mempunyai nilai Zskor yang lebih rendah dibandingkan dengan bayi dengan ASI predominan.

Seperti pada bayi laki-laki, kurva NCHS pada usia 0-24 bulan berada di bawah kurva WHO pada nilai z-skor yg rendah $(<0)$ dan sebaliknya pada nilai z-skor yang tinggi $(>0)$. Setelah usia 24 bulan standar NCHS selalu berada dibawah standar WHO. Dengan demikian dapat diharapkan bahwa bila menggunakan standar WHO maka bayi 0-24 bulan yang mempunyai z-skor $<0$ akan mempunyai z-skor yg lebih rendah bila dibandingkan dengan menggunakan standar NCHS, dan sebaliknya. Artinya, dengan menggunakan standar WHO maka prevalensi stunted pada bayi 0-24 bulan akan lebih tinggi. Keadaan ini sesuai dengan gambaran pada Gambar 13. 


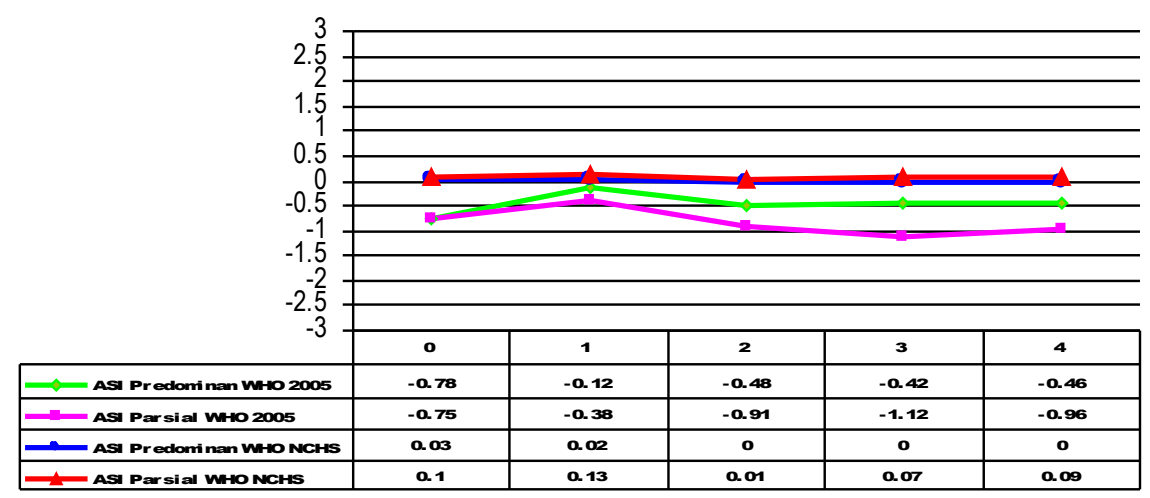

Gambar 12. Nilai Z skor BBIU Bayi Perempuan Menggunakan Standar Antopometri WHO 2005 dan WHO NCHS ( $\mathrm{N}=102)$

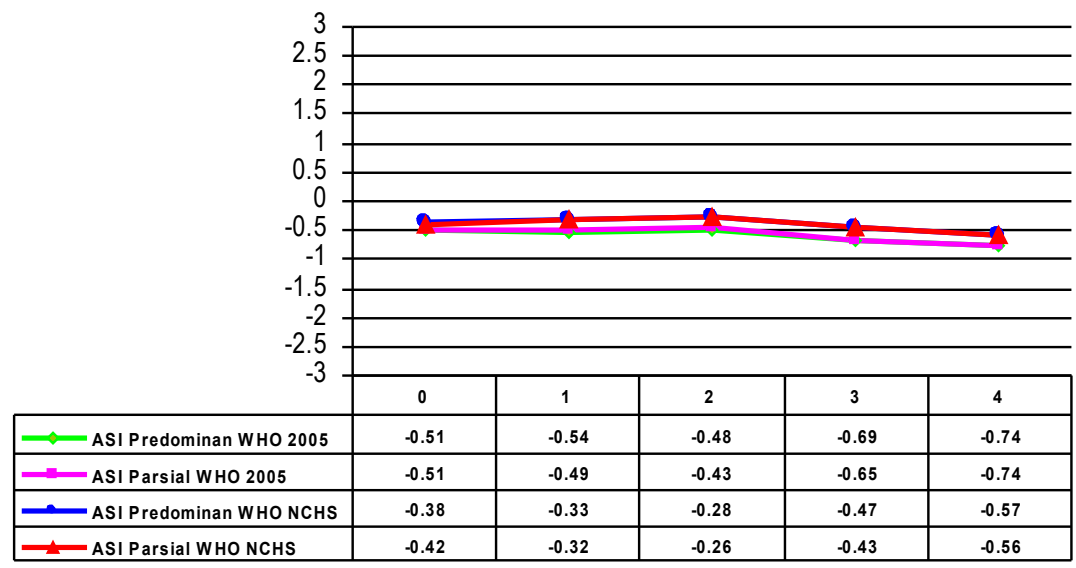

Gambar 13. Nilai Z skor PB/U Bayi Perempuan

Menggunakan Standar Antopometri WHO 2005 ( $N=102)$

Nilai z-skor dengan menggunakan WHO berada di bawah nilai bila menggunakan NCHS, namun pada penelitian ini perbedaannya tidak begitu mencolok, lebih kurang sekitar 0,2 Standar Deviasi (SD).

\section{Berat Badan terhadap Panjang Badan} (anak perempuan)
Pola BB/PB berdasarkan WHO dan NCHS cukup menarik. Nilai Z-skor WHO lebih tinggi pada panjang badan yang lebih rendah, dan sebaliknya pada panjang badan yang lebih tinggi. Dapat diharapkan bahwa menggunakan standar WHO akan memberikan Z-skor yg lebih rendah, dan 
sebaliknya. Berarti prevalensi kurus akan lebih besar bila menggunakan WHO.

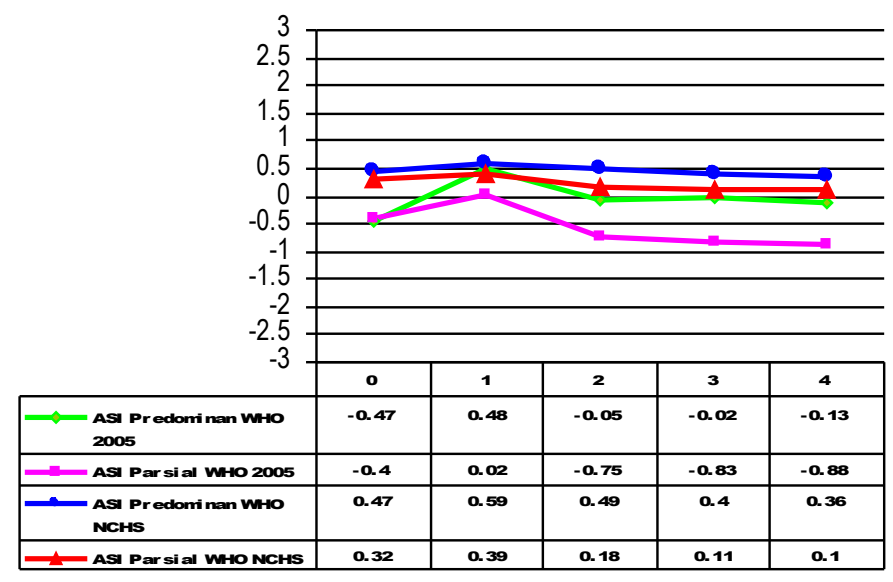

Gambar 14. Nilai Z skor BB/PB Bayi Perempuan Menggunakan Standar Antopometri WHO 2005 dan WHO NCHS (N = 102)

Nilai Z-skor dengan menggunakan WHO 2005 lebih rendah dibandingkan dengan menggunakan NCHS. Nilai Z-skor BB/PB pada bayi dengan ASI parsial lebih rendah dibandingkan ASI predominan, dan terutama sangat jelas pada nilai Z-skor yang menggunakan standar WHO, dengan perbedaan nilai $0,75 \mathrm{SD}$.

\section{DISKUSI}

1. WHO lebih sesuai sebagai standar dibandingkan dengan NCHS

Data penelitian menunjukkan bahwa pola pertumbuhan bayi penelitian pada 2 bulan pertama lebih sesuai (sejajar) dan konsisten dengan standar WHO 2005 dibandingkan standar NCHS, dimana polanya lebih tidak konsisten.

2. Pertumbuhan bayi dengan ASI predominan lebih baik dari bayi ASI parsial

Pencapaian berat bayi ASI parsial (mendapat makanan padat) lebih rendah dari bayi ASI predominan (bayi mendapat air dan madu, selain ASI).
Dari penelitian ini, tampaknya ASI predominan masih cukup baik sebagai alternatif terhadap ASI eksklusif mutlak pada kondisi dimana praktek pemberian ASI eksklusif tidak memungkinkan diberikan.

3. Pola pertumbuhan bayi dipengaruhi oleh pertumbuhan didalam kandungan (retained effect)

Bayi sejak usia 0 bulan mempunyai status gizi dibawah standar WHO, artinya telah terjadi gangguan pertumbuhan sejak di dalam kandungan. Hal ini mempunyai implikasi pada pertumbuhan selanjutnya sebagai akibat retained effect yg dibawa sejak dalam kandungan; yang ditunjukkan dengan kurva pertumbuhan sejajar dengan kurva WHO sampai usia 2 bulan, tetapi tetap dibawah kurva WHO.

4. Kondisi pasca lahir mempengaruhi pertumbuhan bayi lebih jauh

Retained effect ini dapat diperparah dengan kondisi kurang gizi yg berkelanjutan pasca lahir, yang 
didukung oleh deviasi yang semakin lebar dengan bertambahnya usia. Hal ini mungkin dapat dijelaskan oleh pola pemberian makanan kepada bayi yang kurang adekuat setelah usia 2 bulan.

\section{REKOMENDASI}

1. Standar WHO 2005 merupakan standar yang paling merepresentasikan pertumbuhan bayi dan anak, baik ditinjau dari aspek fisiologis maupun metoda yg digunakan. Oleh karena itu, direkomendasikan agar standar WHO 2006 digunakan di Indonesia menggantikan standar WHOINCHS.

2. Pertumbuhan bayi yang diberi ASI eksklusif lebih baik dibandingkan dengan bayi yang tidak diberi ASI eksklusif. Oleh karena itu direkomendasikan untuk meningkatkan promosi praktek pemberian ASI secara intensif.

3. Bayi Indonesia, baik dari penelitian ini maupun dari SUSENAS serta penelitian lain, telah mengalami pertumbuhan yg tidak optimal didalam kandungan seperti yang dibuktikan dengan status gizi bayi pada 0 bulan yang mengalami defisit sebesar 300 gram terhadap standar WHO 2005. Oleh karena dampak hambatan pertumbuhan didalam kandungan akan memberikan retained effect yg akan mempengaruhi pertumbuhan bayi pasca-salin, maka direkomendasikan bahwa perhatian terhadap pertumbuhan bayi sudah dimulai sejak bayi didalam kandungan, yaitu dengan memperbaiki kesehatan dan status gizi lbu hamil.

4. Telah terjadi deviasi atau growth faltering sejak usia sangat dini (2 bulan), yang mengindikasikan sudah adanya masalah pada usia tersebut. Oleh karena itu direkomendasikan untuk memperbaiki pola pemberian makan bayi (ASI) dan pola pengasuhan masalah kesehatan bayi dan anak.

\section{RUJUKAN}

1. Irawati, A (2004). Pengaruh Pemberian Makanan Pendamping ASI Dini terhadap Gangguan Pertumbuhan Bayi Lahir Normal sampai umur 4 bulan. Disertasi Program Doktor Fakultas Kesehatan Masyarakat Universitas Indonesia.

2. Kusharisupeni (1999). Peran Berat Lahir dan Masa Gestasi terhadap Pertumbuhan Linier Bayi di Kecamatan Sliyeg dan Kecamatan Gabus Wetan, Kabupaten Indramayu, Jawa Barat. 1995-1997. Disertasi Program Pascasarjana. Universitas Indonesia.

3. Kusin dan Kardjati, S (editor). Maternal and Child Nutrition in Madura, Indonesia (1994). Royal Tropical Institute the Netherlands, p. $83-110$

4. Utomo B (1996). Health and Social Dimensions of Infant Feeding : Lessons from Indramayu, West Java. A Thesis submitted for the degree of Doctor of Philosophy, Demography Program, Division of Demography and Sociology, Research School of Social Sciences, The Australian National University.

5. De Onis, Mercedes, C. Garza, C.G. Victora, M.K. Bhan and K.R. Norum (2004). The WHO multicenter Growth Reference Study (MGRS): Rationale, Planning, and Implementation. Food and Nutrition Bulletin, Supplement 1.

6. BPS, BKKBN, Depkes dan ORC Macro (2003). Survei Demografi dan Kesehatan Indonesia 2002-2003.

7. WHO (2006). Breastfeeding in the WHO Multicentre Growth Reference Study. Acta Pædiatrica; Suppl 450: 16-26

8. World Health Organization (2006). WHO Child Growth Standards. Methods and Development.

9. World Health Organization (2006). WHO Child Growth Standards. Backgrounder 1-4

10. WHO (2002). The optimal duration of exclusive breastfeeding. Report of an 
Expert Consultation. Geneva: World Health Organization. 